\title{
Penentuan industri kecil pangan unggulan dengan metode SAW dan dampaknya terhadap daya serap tenaga kerja di Kota Jambi
}

\author{
Sesraria Yuvanda*; Deby Aisyah RJ Nur \\ Universitas Muhammadiyah Jambi \\ *E-mail korespodensi: sesra.umjambi@gmail.com
}

\begin{abstract}
Small and Medium Industry (SMI) have an important role in economic development to increase the value of products and providing employment as an industry. The purposes of this research are to determine the leading sector of food small-industry in Jambi City, and to measure the contribution rate of it in absorb labors within the city. The result showed that in Jambi City, the leading sector of food small-industry was a group of nut-processing industry and plantation product-processing industry. That leading sector contributed 18.65 percent to the absorption of labor.
\end{abstract}

Keywords: Industry, Leading sector, Absorption of labor

\begin{abstract}
Abstrak
Industri Kecil Menengah (IKM) mempunyai peranan penting dalam pembangunan ekonomi dalam meningkatkan nilai tambah produk dan penyediaan lapangan kerja sebagai industri. Tujuan penelitian ini untuk menentukan Industri kecil pangan yang menjadi unggulan di kota Jambi, dan untuk menentukan besaran kontribusi industri kecil pangan unggulan dalam memberikan daya serap tenaga kerja di kota Jambi. Hasil penelitian menunjukan bahwa untuk kota Jambi, Industri kecil pangan unggulan adalah kelompok industri olahan kacang-kacangan dan industri pengolahan hasil perkebunan. Industri pangan unggulan tersebut memberikan kontribusi daya serap tenaga kerja sebesar 18,65 persen
\end{abstract}

Kata kunci: Industri, Unggulan, daya serap tenaga kerja

\section{PENDAHULUAN}

Secara makro, kinerja pembangunan ekononi dapat terlihat dari besaran pertumbuhan ekonomi yang diperoleh. Semala semester satu tahun 2020 ekonomi provinsi Jambi terus turun sebesar $-11,2 \%$. Pertumbuhan ekonomi tersebut menjadi negative dikarena pandemic covid 19. Oleh karena itu perlu kerja keras untuk meningkatkan pertumbuhan ekonomi tersebut.

Industri merupakan kegiatan ekonomi yang mengolah bahan-bahan mentah, bahan baku, barang setengah jadi atau barang jadi menjadi barang yang bernilai tinggi (Kartasapoetra, 2000). Sedangkan keberadaan industri yang paling besar menopang perekonomian salah satunya adalah industri kecil menengah.

Industri Kecil Menengah (IKM) mempunyai peranan penting dalam pembangunan ekonomi. Peranan Penting IKM ini dilihat dari penyediaan lapangan kerja sebagai industri. Hal ini sejalan pernyataan Kuncoro (2012), bahwa industri mengalami perkembangan secara bertahap yang membawa perubahan struktur sektor ekonomi yaitu terjadinya penurunan kontribusi sektor pertanian dan meningkatnya sektor industri 
pengolahan. Untuk itu perlu percepatan pembangunan ekonomi daerah oleh pengembangan industrialisasi di daerah.

Sektor industri pengolahan dapat meningkatkan nilai tambah sektor lain dalam menyerap tenaga kerja guna peningkatan pembangunan ekonomi daerah. Hal ini dapat dilihat dari Kontribusi sektor industri pengolahan provinsi Jambi sebesar 10,5\% terhadap PDRB pada tahun 2020. Untuk itu industri pengolahan harus ditumbuhkembangkan lebih cepat guna membangun ekonomi daerah.

Data tahun 2018 menunjukan bahwa total industri kecil Menengah di provinsi Jambi sebesar 30,456 unit usaha. Dari total jumlah industri Kecil menengah yang ada diprovinsi Jambi, mayoritas industri kecil menengah paling banyak berada di kota Jambi yaitu sebesar 20, 3\%.

Salah satu industri kecil yang banyak digeluti oleh masyarakat Kota Jambi adalah industri pengolahan pangan. Pangan adalah segala sesuatu yang berasal dari sumber hayati dan air baik yang diolah maupun tidak diolah dan diperuntukan sebagai makanan atau minuman bagi konsumsi manusia. Termasuk didalamnya adalah tambahan pangan, bahan baku pangan dan bahan lain yang digunakan dalam proses penyiapan, pengolahan dan atau pembuatan makanan atau minuman (Sobari. E, 2018).

Untuk khusus Kota Jambi, kategori Industri yang memiliki unit usaha paling banyak adalah industri pangan yaitu sebesar 2,008 unit usaha. Ini berarti keberadaan industri pangan olahan dikota Jambi juga mempunyai makna yang besar terhadap ekonomi daerah dalam menciptakan nilai tambah dan menampung tenaga kerja di kota Jambi. Sejalan dengan pendapat Taib, G dan Roswita, R. (2018), perlu pengembangan industri pangan karena industri ini mempunyai prospek pemasaran yang baik.

Menumbuhkembangkan industri pangan akan berdampak pula terhadap peningkatan nilai gizi masyarakat dan pendayagunaan sumber daya lokal khususnya produk tanaman pangan di kota Jambi. Disisi lain industri tersebut juga dapat menyediakan lapangan kerja atau menampung calon tenaga kerja untuk mendapatkan pekerjaan khususnya di kota Jambi.

Tertarik untuk meneliti dan membahas pengembangan industri pangan olahan dan kaitan dengan daya tampung tenaga kerja maka perlu dilakukan penelitian yang akan dapat memberikan solusi bagi upaya menumbuhkembangkan industri pangan di kota Jambi yang berdampak bagi daya tampung tenaga kerja. Penelitian tersebut akan berjudul "Penentuan industri kecil pangan unggulan dengan metode saw dan dampaknya terhadap daya serap tenaga kerja di Kota Jambi”

\section{METODE}

Metode yang digunakan pada penelitian ini adalah metode penelitian deskriptif kuantitatif. Untuk data yang digunakan adalah data sekunder yang diperoleh dari Dinas Perindustrian dan Perdagangan Provinsi Jambi.

Untuk menetapkan industri kecil pangan unggulan digunakan model SAW (Simple Additive Weighting). Sistematika dalam Model SAW menggunakan matriks keputusan (X) dengan membandingkan rating alternative yang ada (Kusumadewi, dkk, 2006). Alasan pemilihan model ini karena mempunyai keunggulan adalah: 1).Melakukan penilaian lebih tepat yang didasarkan pada nilai krieria dan bobot dari alternative yang telah ditentukan. 2).Selain itu model SAW juga akan menentukan perankingan setelah menentukan nilai bobot, Darmastuti, (2013). 2).Perhitungan nilai atribut normalisasi sesuai dengan nilai atribut (Affifah, 2012)

Model SAW ini menetapkan industri kecil pangan yang menjadi unggulan dengan 4 tahapan yaitu: 1).Penentuan Kriteria dan pembobotan, 2).Penentuan nilai setiap 
alternative produk unggulan, 3).Normalisasi Matriks, 4).Pengambilan Keputusan ranking unggulan

Setelah menetapkan industri pangan unggulan di kota Jambi, tahap selanjutnya menganalisis kontribusi industri pangan unggulan terhadap daya serap tenaga kerja dengan hitungan matematis :

$$
\text { kontribusi TKIP }=\frac{\text { total TK IP }}{\text { Total TK Ind }} \times 100
$$

Dimana:

TKIP = Kontribusi daya tampung tenaga kerja industri pangan

TKIP $=$ Total tenaga kerja industri pangan

TK Ind $=$ Total tenaga kerja industri

\section{HASIL DAN PEMBAHASAN}

Dalam menentukan industri unggulan Pangan kota Jambi digunakan model SAW (simple additive weighting). Untuk menggunakan model SAW tersebut dilakukan melalui 4 tahapan. Adapun keempat tahap tersebut adalah:

\section{Penentuan kriteria dan pembobotan}

Untuk menentukan industri unggulan pangan Kota Jambi digunakan 5 kriteria. Kelima kriteria tersebut adalah unit usaha, tenaga kerja, nilai produksi, nilai investasi, dan nilai kapasitas. Bobot dari kelima kriteria tersebut dimuat pada Tabel 1 berikut ini:

Tabel 1. Bobot kriteria penentuan produk unggulan industri kecil pangan unggulan

\begin{tabular}{clcc}
\hline No & \multicolumn{1}{c}{ Kriteria } & Kode & Bobot \\
\hline 1 & Unit usaha & C. 1 & 0.200 \\
2 & Tenaga kerja & C. 2 & 0.133 \\
3 & Nilai produksi & C. 3 & 0.333 \\
4 & Nilai investasi & C. 4 & 0.067 \\
5 & Nilai kapasitas & C. 5 & 0.267 \\
\hline
\end{tabular}

Sumber: Data diolah, 2020

\section{Penentuan nilai setiap alternatif produk unggulan}

Berdasarkan 5 kriteria yang bobotnya telah ditetapkan dilakukan penetapan nilai setiap alternatif dari industri unggulan Pangan. Adapun hasil penetapan nilai alternatif tersebut disajikan pada Tabel 2 berikut ini.

Tabel 2. Nilai setiap industri kecil pangan unggulan

\begin{tabular}{clccccr}
\hline \multirow{2}{*}{ No } & Kelompok industri & \multicolumn{6}{c}{ Kode } \\
\cline { 3 - 7 } & kecil pangan & C.1 & C.2 & \multicolumn{1}{c}{ C.3 } & \multicolumn{1}{c}{ C.4 } & \multicolumn{1}{c}{ C.5 } \\
\hline 1 & Umbi-Umbian & 2 & 15 & $736,000,000$ & $700,000,000$ & $57,200.00$ \\
2 & Hasil Perkebunan & 6 & 23 & $450,400,000$ & $270,000,000$ & $907,150.00$ \\
3 & Hasil laut & 1 & 5 & $48,000,000$ & $2,500,000$ & 720.00 \\
4 & Olahan Kacang- & & & & & \\
& kacangan & 5 & 40 & $2,589,200,000$ & $544,000,000$ & $9,574,200.00$ \\
\hline
\end{tabular}

Sumber: Data diolah, 2020

\section{Perlakuan normalisasi matrik}

Hasil penetapan nilai setiap alternatif Industri Pangan Unggulan kota Jambi dilakukan normalisasi terhadap matrik hasilnya. Matrik ternormalisasi Industri Pangan Unggulan dipaparkan pada tabel 3. 
Tabel 3. Matrik ternormalisasi industri kecil pangan unggulan

\begin{tabular}{llccccc}
\hline \multirow{2}{*}{ No Kelompok Industri Kecil Pangan } & \multicolumn{5}{c}{ Kode } \\
\cline { 3 - 7 } & & C.1 & C.2 & C.3 & C.4 & C.5 \\
\hline 1 & Umbi-umbian & 0.333 & 0.375 & 0.284 & 1.000 & 0.006 \\
2 & Hasil perkebunan & 1.000 & 0.575 & 0.174 & 0.386 & 0.095 \\
3 & Hasil laut & 0.167 & 0.125 & 0.019 & 0.004 & 0.000 \\
4 & Olahan kacang-kacangan & 0.833 & 1.000 & 1.000 & 0.777 & 1.000 \\
& Bobot & 0,200 & 0,133 & 0,333 & 0,067 & 0,267 \\
\hline
\end{tabular}

Sumber: Data diolah, 2020

Pengambilan keputusan ranking industri kecil pangan unggulan di Kota Jambi

Pengambilan keputusan untuk penetapan Industri Kecil Pangan Unggulan di Kota Jambi dilakukan dengan mengkalikan hasil matrik ternormalisasikan dengan vektor bobot kriteria yang digunakan untuk penentuan industri unggulan. Matrik hasil perkalian tersebut disajikan pada Tabel 4 berikut ini.

Tabel 4. Matriks keputusan industri pangan unggulan di Kota Jambi

\begin{tabular}{clcc}
\hline No & Kelompok industri kecil pangan & Nilai total & Ranking unggulan \\
\hline 1 & Pengolahan umbi-umbian & 0.280 & III \\
2 & Pengolahan hasil perkebunan & 0.386 & II \\
3 & Pengolahan hasil laut & 0.056 & IV \\
4 & Pengolahan kacang-kacangan & 0.952 & I \\
\hline
\end{tabular}

Sumber: Data diolah, 2020

Dari paparan Tabel 4 terlihat bahwa terpilih industri olahan kacang-kacangan sebagai Industri Kecil Pangan Unggulan pertama. Sedangkan industri hasil perkebunan menjadi industri pangan unggulan kedua dan industri pangan unggulan ketiga terpilih adalah industri Umbi-umbian dan diikuti oleh industri Olahan laut.

Industri pangan berperan besar dalam menyerap tenaga kerja di Kota Jambi. hal ini terlihat dari kontribusi industri pangan dalam menyediakan lapangan kerja bagi tenaga kerja produktif dikota Jambi. Terlihat daya serap tenaga kerja industri kecil pangan dalam menyediakan produk tersebut cukup besar yaitu sebesar 18,65 persen kontribusinya terhadap lapangan kerja industri di kota Jambi seperti terlihat pada tabel dibawah ini.

Tabel 5. Kontribusi daya serap tenaga kerja oleh industri pangan terhadapat industri di Kota Jambi

\begin{tabular}{|c|c|c|c|}
\hline Kategori & & Tenaga Kerja (orang) & Kontribusi (\%) \\
\hline Industri Pangan & & 5.611 & 18,65 \\
\hline \multicolumn{4}{|l|}{ Non Industri pangan } \\
\hline a. Sandang & & 2.714 & 9,02 \\
\hline $\begin{array}{l}\text { b. logam } \\
\text { elektronik }\end{array}$ & dan & 3.949 & 13,13 \\
\hline $\begin{array}{l}\text { c. kimia dan } \\
\text { bangunan }\end{array}$ & bahan & 8.508 & 28,28 \\
\hline d. kerajinan & & 9.305 & 30,92 \\
\hline e. total Industri & & 30.087 & 100 \\
\hline
\end{tabular}

Sumber: Data diolah, 2020 
Tabel 5 memperlihatkan kontribusi industri pangan masih kecil dibandingkan dengan kontribusi kimia dan bahan bangunan dan industri kerajinan. Dimana masingmasingnya memiliki kontribusi sebesar 28,28 persen dan 30,92 persen. Akan tetapi industri pangan masih unggul kontribusinya dibandingkan dengan industri sandang dan industri logan dan elektoronik, masing-masing sebesar 9,02 persen dan 13,13 persen.

\section{Implikasi Kebijakan}

Untuk menumbukembangkan industri kecil pangan di kota Jambi dimasa datang maka diperlukan kebijakan yang terkait dengan industri unggulan pangan yang terpilih. Hasil perhitungan menunjukan industri kecil pangan unggulan yang terpilih adalah industri olahan kacang-kacangan. Ini berarti diperlukan dukungan input, peningkatan nilai tambah dalam prosesing dan pemasaran output dari industri yang terpilih tersebut. Untuk itu diperlukan minimal 3 kebijakan yang terkait dengan penumbuhkembangan industri pengolahan kacang-kacangan sebagai industri pangan unggulan.

Ketiga kebijakan minimal yang harus diambil untuk menumbuhkembangkan industri pangan unggulan tersebut adalah: 1).Dukungan penyediaan bahan baku kacangkacangan dari hasil pertanian tanaman pangan berupa kacang-kacangan seperti kacang kedelai, kacang tanah, kacang hijau, kacang mete, kacang merah, dan kacang polong. Untuk itu dinas pertanian khususnya sub bidang pertanian tanaman pangan perlu ditumbuhkembangkan di kota Jambi dan mendapat pula dukungan dari kabupaten Muara Jambi dan Kabupaten Batanghari sebagai sentra pendukung tanaman kacangkacangan. Pemerintah kota Jambi harus bekerjasama dengan 2 kabupaten tersebut untuk memperkuat bahan baku guna penyediaan industri tersebut. 2).Kebijakan peningkatan nilai tambah produksi melalui penggunaan teknologi dan diversifikasi produk kacangkacangan yang higienis dan layak pasar. Untuk itu diperlukan peningkatan kualitas produk, desain produk dan rasa produk yang menarik bagi konsumen di Kota Jambi. 3).Kebijakan dukungan pemasaran bagi para pengusaha industri pangan olahan yang terpilih melalui kerjasama dengan supermarket dan mini market yang ada di kota Jambi. dinas perindustrian dan perdagangan kota Jambi harus aktif membantu mempromosikan produk kacang-kacangan yang dihasilkan industri kecil unggulan tersebut melalui expose produk kuliner yang terbuat dari kacang-kacangan yang berkualitas dan berselera tinggi.

\section{KESIMPULAN DAN SARAN}

\section{Kesimpulan}

Industri Kecil Pangan yang menjadi unggulan pertama adalah industri olahan Kacang-kacangan. Sedangkan industri Pengolahan hasil Perkebunan terpilih menjadi industri pangan unggulan kedua dan Industri pangan unggulan ketiga terpilih adalah industri hasil olahan umbi-umbian. Industri pangan unggulan tersebut memberikan kontribusi daya serap tenaga kerja sebesar 18,65 persen di kota Jambi

\section{Saran}

Untuk memperkuat penumbuhkembangan industri pangan unggulan yang terpilih maka disarankan Pemerintah Kota Jambi harus melakukan kerjasama dengan kabupaten Batanghari dan Muaro Jambi untuk penyediaan bahan buku bagi kebutuhan industri. Untuk meningkat daya serap tenaga kerja pada industri olahan kacang-kacangan maka pemerintah perlu membantu invovasi produk dan peningkatan produksi sehingga dapat menyerap tenaga kerja lebih banyak lagi. 


\section{DAFTAR PUSTAKA}

Afifah, N. (2012). Sistem pendukung keputusan penerima beasiswa magang menggunakan metode simple additive weighting. Madura. Magistra No. 93, 32-37

Darmastuti, D. (2013). Implementasi metode simple additive weighting (saw) dalam informasi lowongan kerja berbasis WEB untuk rekomendasi pencari kerja terbaik. Jurnal Sistem Teknologi dan Informasi.1(2), 114-119

Hidayat, M,S dan Rasjid, M, R (2018). The analysis of regional investment model for improving development: the case of Bungo District. The Journal of Social Sciences Research. 4(12), 377-382

Kartasapoetra, G. (2000). Makro ekonomi. edisi kedua, cetakan keempat belas. Raja Grafindo Persada: Jakarta

Kuncoro, M. (2012). Ekonomika aglomerasi dinamika \& dimensi spasial kluster industri indonesia. UPP STIM YKPN: Yogyakarta.

Kusumadewi, S. Hartati, S., Harjoko, A., Wardoyo, R., (2006). Fuzzy multy atribut decision making (Fuzzy MADM). Graha Ilmu: Yogyakarta

Sobari, E. (2018). Teknologi pengolahan pangan. prinsip dan praktik. Andi: Yogyakarta

Taib, G dan Roswita, R. (2018). Analisis prospek dan kendala pengembangan produk industri pangan lokal di Sumatera Barat. Teknologi Pertanian Andalas. Volume 22(1), 96-101

Wilantara, RF dan Susilawati (2016). Strategi dan kebijakan pengembangan UMKM. Refika Aditama: Bandung

Yuvanda, S., RM, Rachmad., Zamzami., Syafri, M. (2020). Development on the leading small and medium-sized industry (SMI) : Food Industry in Jambi Province. Journal Perspektif Pembiayaan dan pembangunan Daerah. 8(3), 311-318 